\title{
LEGAL INSTITUTIONAL FRAMEWORK FOR SPECIAL ECONOMIC ZONES IN LATVIA
}

\author{
Sandra Ezmale \\ Dr.oec, assistant professor, lead researcher, Rezekne Academy of Technologies, Rezekne, \\ Latvia, e-mail: sandra.ezmale@rta.lv
}

\begin{abstract}
The regulatory framework of the freeports and special economic zones of Latvia are analysed in the paper providing as well an insight into the changes related to granting aid that have taken place. There are five freeports and special economic zones in Latvia, though, while the conditions for granting the aid are the same, the way they operate varies. The research aims to describe the institutional framework of special economic zones in Latvia. The author (1) has carried out a study on scope and conditions for granting the aid in the freeports and special economic zones of Latvia; (2) has described the restrictions on granting the aid. The monographic research and comparative analyses methods are used in the research.
\end{abstract}

Keywords: special economic zones, free ports, regional aid, tax incentives. JEL code: R 5.

\section{Introduction}

There still exist some notable linguistic and conceptual differences in the definition and typology of free economic zones (FEZ). Many countries have their own terminology describing FEZs, for example, Mexico refers to its zones as "maquiladoras", Ghana, Cameroon, and Jordan have "industrial free zones", the Philippines calls it "special export processing zones", Russia has "free economic zones", Latvia - "special economic zones" and "freeports" (Ežmale, Rimšane, 2014). However, the special economic zones and freeports of Latvia operate under one legal framework.

Considering that economic zones develop expansively, several types of economic zones can be distinguished; the terms "special economic zone", "free economic zone", "freeport" etc. are used freely without accentuating differences and thus creating a conception that all above mentioned terms are with one and the same meaning (Ziedina, Pelse, 2017).

Gulbis (2018) argues that one of the most popular tools for attracting foreign direct investments (FDI) is the special economic zone (SEZ). The peculiarities of the zones may vary, still, they always offer a better business environment within their territory, compared with the rest of the country. Usually, the advantage is achieved by offering tax incentives, a simplified legal framework, access to better financial solutions, and other benefits. The aim is to encourage potential investors to invest in the specific territory and to create new employment opportunities with all the added value that comes along with it. Latvia is not an exception with its five SEZs established (Gulbis, 
2018). Latvia's experience sustains the basic characteristics of the economic zones and demonstrates the importance of proper understanding of the economic zones' competitive advantages (Ziedina, Pelse, 2017). Rankevica outlines that the establishment of individual territories - free economic zones - where certain tax incentives are applied is one of the possibilities for attraction of investments using tax relief policy as a mean (Rankeviča, 2006).

Despite differences in the nomenclature and typology, each FEZ operates to increase trade by offering special trade/production incentives to stimulate local and foreign investment within the region. In general, FEZs are established to achieve fiscal, social, and regional policy goals of the country, and the most important fiscal goal of the SEZ is to facilitate economic growth through the use of the reduced tariffs and more efficient customs control (Ezmale, Rimsane, 2014).

The Latvian researchers have discussed the theory and practice of the FEZs from various points of view. Mostly, the researchers have investigated the impact of Latvia's special economic zones to development of the regions; nevertheless, the legal framework is one of the most important issues affecting the operation and performance of Latvia's special economic zones and freeports (Rankeviča, 2006). The lower competitiveness of the European FEZs in comparison with the most successful FEZs of the world can be explained by the fact that the European Commission determines and limits the conditions for the commercial aid granted to the enterprises operating in the FEZs (Ezmale, Rimšane, 2014). Therefore, the aim of the research is to describe the institutional framework for special economic zones in Latvia. The following tasks are defined: (1) to carry out a study on the scope and conditions for granting the aid in the freeports and special economic zones of Latvia; (2) to describe the restrictions on granting the aid in the special economic zones and freeports of Latvia. The monographic research and comparative analyses methods are used in the research.

\section{Scope and conditions for granting the aid}

There are five special economic zones and freeports in Latvia. The Liepaja Special Economic Zone (hereinafter - the LSEZ) was established in 1997 (Law of the Republic of Latvia, 1997), the Rezekne Special Economic Zone (hereinafter - the RSEZ) was established in 1997 as well (Law of the Republic of Latvia, 1997), the Latgale Special Economic Zone (hereinafter the LaSEZ) was established in 2016 (Law of the Republic of Latvia, 2016). The Free Trading Port of Riga was established in 1996 and transformed into the Freeport of Riga (hereinafter - RBO) in 2000 (Law of the Republic of Latvia, 2000), and the Freeport of Ventspils (hereinafter - VBO) was established in 1996 (Law of the Republic of Latvia, 1996). 
The tax incentives in the LSEZ and the RSEZ have been applied since 1997, when the zones were established by the special laws; however, the RBO and the VBO started to apply tax relief in 2002, when the Law "On Taxation in Free Ports and Special Economic Zones" came into effect.

The scope of the tax incentives granted, or the scope of the aid applicable to investments, has changed several times since 2002 (see: Table 1)

\section{Table 1 Scope of the aid applicable to investments in special economic zones and in freeports in 2001-2020}

\begin{tabular}{|c|c|c|c|}
\hline Period & $\begin{array}{c}\text { Large } \\
\text { company }\end{array}$ & $\begin{array}{c}\text { Medium sized } \\
\text { company }\end{array}$ & Small company \\
\hline $01.01 .2002-19.06 .2003$ & $50 \%$ & $50 \%$ & $50 \%$ \\
\hline $20.06 .2003-31.12 .2006$ & $50 \%$ & $65 \%$ & $65 \%$ \\
\hline $01.01 .2007-30.06 .2014$ & $50 \%$ & $60 \%$ & $70 \%$ \\
\hline $01.07 .2014-2020$ & $35 \%$ & $45 \%$ & $55 \%$ \\
\hline
\end{tabular}

A capital company of the LSEZ/ RSEZ/LaSEZ and a licenced capital company of the RBO/VBO is eligible to the aid in the form of an $80 \%$ deduction on the corporate income tax and an $80 \%+20 \%$ (eventually $100 \%$ ) tax deduction on the real estate tax (Law of the Republic of Latvia, 2001).

Table 2 Direct tax incentives

\begin{tabular}{|l|c|c|}
\hline $\begin{array}{c}\text { Taxes subject to the } \\
\text { application of incentives }\end{array}$ & $\begin{array}{c}\text { Tax rate for a company operating in } \\
\text { the status of SEZ/ freeport enterprise }\end{array}$ & $\begin{array}{c}\text { Tax rate in } \\
\text { Latvia }\end{array}$ \\
\hline $\begin{array}{l}\text { Corporate income tax } \\
\text { applicable on dividends }\end{array}$ & $4 \%$ & $20 \%$ \\
\hline Real estate tax & $0.3-0 \%$ & $1.5 \%$ \\
\hline
\end{tabular}

From 2018 in Latvia, the corporate income tax on reinvested or undistributed profit is $0 \%$, while an $80 \%$ discount is applicable to dividends in Rezekne SEZ (Rezekne SEZ Authority, 2018).

Upon concluding a contract with the SEZ Authority, an enterprise may commence a procedure for the creation of a free custom zone in order to receive a permit for the performance of commercial activity in the free zone regime within the territory of the RSEZ. The free custom zone regime, which includes indirect tax incentives and special customs control measures, is applied to such enterprises. The indirect tax incentives ( $0 \%$ rate on VAT) is applied to the supplies of goods within the free custom zone of the special economic zone for the further export. 
In 2014, the requirement came into effect stipulating that the sum of all applicable tax incentives should not exceed the maximum amount of the direct tax incentives on investments, which is estimated by the amount of the investment and the maximum aid applicable according the size of the company, and determined in the investment contract (Law of the Republic of Latvia, 2001). Therefore, the procedure was defined regulating how the investments made before 2014 are included in the amount of the accrued investments, which is subject to the aid:

1) 1997 - December 31, 2001: investments made by the capital companies of Liepaja and Rezekne until 2002, before adoption of the Law "On Taxation in Free Ports and Special Economic Zones" were included in the amount of accrued investments and were subject to the aid rate that was in effect in 2002;

2) 2002 - June 19, 2003: the investments actually made during that period are subject to the aid rate that was in effect during that period, i.e., not more than $50 \%$, irrespective of the size of the company;

3) June 20, 2003 - December, 2006: the investments actually made during that period are subject to the aid rate that was in effect during that period, i.e., $50-65 \%$;

4) $2007-2013$ [until June 30, 2014]: the investments actually made during that period are subject to the aid rate that was in effect during that period, i.e., 50-70\% (Ministry of Finances of the Republic of Latvia, 2015)

A sum of accumulated investments is the sum of all the investments made by the capital company or the licensed capital company of the zone, commencing from the taxation period when the investment company has signed a contract on the investments in the zone or free port territory with the zone or free port Authority until (and including) the taxation period, for which the calculation is made. It refers to a LSEZ capital company, a RSEZ capital company, a LaSEZ capital company, a RBO licensed capital company, or a VBO licensed capital company (Law of the Republic of Latvia, 2001).

Meanwhile, the amendments to the law adopted on April 4, 2013 (in effect since May 9, 2013) have introduced the term 'investment contract' obliging to fix investments for the coming 5 years, providing that the investments actually made after June 30, 2014 became eligible for granting the aid valid before June 30,2014, only in case the investment contract was concluded until June 30, 2014 for a period not exceeding 5 years.

The condition of concluding an 'investment contract' which may include investments with a maximum term of 5 years from the date of the contract is operational after July 1, 2014 as well. In the contract, it is mandatory to 
specify the maximum amount of direct tax incentives that may be applied to the investments covered by the contract.

\section{Permit to apply direct tax incentives}

The necessity to issue a permission for application of direct tax incentives derives from five laws on the special zones/ freeports. Hence, the capital company licensed by the authority of the RBO and VBO is awarded a certificate granting rights to apply direct tax relief, while the SEZ capital company of the RSEZ and the LaSEZ is awarded a permission granting rights to apply direct tax relief.

In order to receive a permission, a capital company shall be located and shall conduct business only in the territory of the RBO, VBO, LSEZ, LaSEZ, or RSEZ (Law of the Republic of Latvia, 2001). Permission to apply direct tax relief does not refer to the following:

- aid granted on the condition that domestic goods are used over imported goods;

- capital company subject to an outstanding recovery order following a preceding decision of the Commission declaring the aid illegal and incompatible with the internal market;

- capital company in difficulties;

- capital company that has terminated the same or similar activities in the European Economic Area in the two years preceding the submission of the application for the investment contract, or has specific plans to terminate such activities within two years after the completion of the investment project defined in the investment contract (same activity or similar activity is an activity that falls within the same class of NACE Rev. 2 statistical classification of economic activities; four-digit code) (Law of the Republic of Latvia, 2001).

The permit/certificate issued by the Authority of the LSEZ, RSEZ, RBO, or VBO certifies the right, as provided in the Law, to receive the direct tax relief starting from the taxation period when the permit for application of the direct tax relief is granted and the investment contract has come into the effect.

In addition to granting the permit, there are restrictions on the capital companies operating in certain sectors:

- transport sector (commercial passenger transport by air, sea, road, rail, and inland waterway, or freight) and transport infrastructure;

- steel industry;

- agriculture;

- $\quad$ synthetic fibres sector; 
- fisheries and aquaculture;

- coal industry;

- shipbuilding;

- energy production, distribution, and infrastructure (Law of the Republic of Latvia, 2001).

Capital companies in these sectors may not be granted the permit for application of the direct tax relief unless the capital company also operates in another sector (s) and clearly distinguishes the financial flows of the supported sector from the financial flows of other (non-eligible) economic activities during the period of investing and throughout all the period of the application of the tax incentives (the incomes/expenses of a particular economic activity and the related direct and indirect costs are recorded separately in the accounting).

The investment contract sets out the conditions for the application of direct tax incentives to the investments covered by the contract. The investment is eligible if it meets the following criteria:

- they are long-term tangible investments (buildings, structures, machinery and equipment) and intangible investments (costs for obtaining patents and acquiring technologies);

- $\quad$ they are provided in the investment contract;

- they may qualify as initial investment;

- $\quad$ assets acquired are new, except in the case of small and mediumsized enterprises (SMEs);

- $\quad$ investments must remain in the LSEZ/ RSEZ/ LaSEZ/ RBO or VBO for at least 5 years after investing or, in the case of SMEs, at least 3 years after investing (Ministry of Finance, 2014).

However, investments qualify as initial investments if they are invested: (1) in establishing a new capital company; (2) in increase of the production or service capacity of an existing capital company; (3) in diversifying the output of an existing capital company launching the products not previously produced by the capital company; (4) in a major change of the production processes of an existing capital company.

For the acquisition of intangible assets, the following criteria shall be satisfied:

- $\quad$ they shall be used only at the place of business where the aid is granted;

- $\quad$ they shall be subject to depreciation;

- they shall be purchased according the market conditions from the third parties unrelated to the buyer;

- they shall be included in the assets of the recipient capital company for at least five years or, in the case of SMEs, three years, and shall 
be linked to the project that is granted the aid (EC Regulation, 2014).

\section{Ensuring transparency of the aid granted}

Acapital company of the RSEZ/ LSEZ/ LaSEZ or a capital company licensed by the RBO/ VBO that is subject to direct tax relief shall submit the following information to the State Revenue Service of the Republic of Latvia along with the annual report: a review on the application of the corporate income tax relief within the taxation period; information about other aid received for the initial investment, including de minimis aid granted for the same eligible costs, a statement of the amount of accumulated direct tax relief and the amount of the investment accrued (Law of the Republic of Latvia, 2001).

However, the local government shall submit a report on the application of the real estate tax relief during the taxation period to the capital companies that are granted the application of direct tax relief by May 1 of the posttaxation year.

The Authorities of the LSEZ, RSEZ, LaSEZ, RBO and VBO publish information about the aid granted on their website and ensures that this information is up-to-date and available for at least 10 years from the last year/taxation period when the capital company of the LSEZ, RSEZ, LaSEZ, RBO or VBO has applied the direct tax relief in accordance with the law.

The Authorities of the LSEZ, RSEZ, LaSEZ, RBO and VBO also publish information on each individual aid granted in the system administered by the European Commission for ensuring aid transparency Aid Award System Application. The data entry into the EC-administered system for aid transparency Aid Award System Application is carried out in accordance with the Regulations of the Cabinet of Ministers No. 386 "Procedures for publication of information on business aid granted and for granting and annulling rights for use of the electronic system" (in effect since July 1, 2016). The data published in the EC-administered system for aid transparency Aid Award System Application is publicly accessible and available for processing using the tools provided (Ministry of Finance of the Republic of Latvia, 2019).

\section{Conclusions and suggestions}

Analyses of the regulatory framework determining the operation of Latvia's special economic zones and free ports leads to the following conclusions:

1. Despite the fact that each of the five special economic zones and freeports of Latvia has its own law determining the peculiarities of 
their operation, the conditions for granting the aid are the same in all the zones and free ports of Latvia.

2. In order to qualify for the aid, the enterprise shall carry out an economic activity in territory of the special economic zone or free port.

3. Depending on the status of the company defining it as a small, medium-sized or large enterprise, it may be subject to the aid in the form of tax incentives amounting up to $35-55 \%$ of the sum of initial investments according the current legislation.

4. Companies are subject to the aid in the form of direct tax relief or $80 \%$ corporate income tax relief on the sum calculated (from 1 January 2018, applicable to the dividend tax), and $80 \%+20 \%$ (eventually $100 \%$ ) real estate tax relief.

5. There are restrictions on granting direct tax relief to a number of economic activities such as transport, agriculture, shipbuilding, etc.

6. Information on the aid granted is published in the EC-administered system for ensuring the aid transparency Aid Award System Application.

In order to increase the competitiveness of the Latvian special economic zones and free ports, the author proposes the following:

1) to expand the list of eligible investments adding the expected wage costs;

2) to expand the list of eligible investments adding the costs related to the leasing of tangible assets (financial lease);

3 ) to clarify the definition of tangible and intangible investments in accordance with the list of investments provided in the Commission Regulation No. 651/2014 of June 17, 2014;

4) to provide personal income tax relief for the Latgale special economic zones.

\section{References}

1. EK regula (2014). KOMISIJAS REGULA (ES) Nr. 651/2014 ar ko noteiktas atbalsta kategorijas atzīst par saderīgām ar iekšējo tirgu, piemērojot Līguma 107. un 108. pantu. Retrieved from https://eur-lex.europa.eu/legal-content/LV/TXT/ HTML/?uri=CELEX:32014R0651\&from=LV

2. Ezmale, S., Rimsane, I. (2014). Promoting the Plurilingual Awareness in Business Environment: Case of Rezekne Special Economic Zone. Procedia - Social and Behavioral Sciences, Vol. 110, 24 January 2014, pp. 231-240. Retrieved from https://www.sciencedirect.com/science/article/pii/S1877042813055067

3. Gulbis, I. (2018). Foreign direct investment and special economic zones in Latvia. Baltic Journal of Real Estate Economics and Construction Management. 2018, 6, pp. 240-252. Retrieved from https://www.researchgate.net/publication/329777514_ Foreign_Direct_Investment_and_Special_Economic_Zones_in_Latvia

4. LR Finanšu ministrija (2015). Tiešo nodoklu atvieglojumi brīvostās un speciālajās ekonomiskajās zonās. 08.01.2015. Nepublicētie semināra materiāli. 
5. LR Finanšu ministrija (2019). Komercdarbības atbalsta kontrole. Pārredzamības sisitēma. Retrieved from https://www.fm.gov.lv/lv/sadalas/komercdarbibas_ atbalsta_kontrole/valsts_atbalsta_parredzamiba/parredzamibas_sistema/

6. LR likums (2016). Latgales speciālās ekonomiskās zonas likums. Latvijas Vēstnesis, 108 (5680). Retrieved from https://likumi.lv/ta/id/282586-latgales-specialasekonomiskas-zonas-likums

7. LR likums (1997). Liepājas speciālās ekonomiskās zonas likums, Latvijas Republikas Saeimas un Ministru Kabineta Ziṇotājs, 6, 27.03.1997. Retrieved from https://likumi.lv/doc.php?id=42426

8. LR likums (1997). Rēzeknes speciālās ekonomiskās zonas likums, Latvijas Republikas Saeimas un Ministru Kabineta Ziṇotājs, 22, 27.11.1997. Retrieved from https://likumi.lv/doc.php?id=45469

9. LR likums (2000). Rīgas brīvosts likums, Latvijas Republikas Saeimas un Ministru Kabineta Zin,otājs, 8, 20.04.2000. Retrieved from https://likumi.lv/ doc.php?id=3435

10. LR likums (2001). Par nodokḷu piemērošanu brīvostās un speciālajās ekonomiskajās zonās, Latvijas Republikas Saeimas un Ministru Kabineta Ziṇotājs, 17, 06.09.2001. Retrieved from https://likumi.lv/doc.php?id=33419

11. LR likums (1996). Ventspils brīvostas likums, Latvijas Republikas Saeimas un Ministru Kabineta Ziṇotājs, 3, 13.02.1997. Retrieved from https://likumi.lv/ doc.php?id=41737

12. Rankevica, V. (2014). Free economic zones in Latvia and their regional impact. Resume of the PhD Paper for the scientific degree of Dr.oec. Retrieved from https://llufb.llu.lv/dissertation-summary/economy/Kopsavilkums-ViktorijaRankevica.pdf

13. Rezekne SEZ Authority (2018). Support for investors. Rezekne SEZ Authority. Retrieved from http://www.rsez.lv/index.php/en/support-to-investors

14. Ziedina, D., Pelse, M. (2017). Main characteristics of economic zones types: Latvia's experience. Proceedings of the 2017 International Conference "ECONOMIC SCIENCE FOR RURAL DEVELOPMENT”, No. 44, Jelgava, LLU ESAF, 27-28 April 2017, pp. 212218. Retrieved from http://llufb.llu.lv/conference/economic_science rural/2017/Latvia_ESRD_44_2017-212-218.pdf 